\title{
Prohexadione calcium on shoot growth of 'Starkrimson' pear trees
}

\author{
Mateus da Silveira Pasa(1) and Todd Einhorn ${ }^{(2)}$ \\ (1)Empresa de Pesquisa Agropecuária e Extensão Rural de Santa Catarina, Estação Experimental de São Joaquim, Rua João Araújo \\ Lima, no 102, Caixa Postal 81, Jardim Caiçara, CEP 88600-000 São Joaquim, SC, Brazil. E-mail: mateuspasa@epagri.sc.gov.br \\ (2)Michigan State University, Department of Horticulture, 1066 Bogue Street East Lansing, MI 48824, USA. E-mail: einhornt@msu.edu
}

\begin{abstract}
The objective of this work was to evaluate the fruiting and vegetative growth of 'Starkrimson' pear in response to the application of prohexadione calcium (P-Ca). P-Ca $\left(250 \mathrm{mg} \mathrm{L}^{-1}\right)$ was sprayed to scaffold limbs and to whole trees in commercial orchards. A randomized complete block design was used to minimize declivity effects. Vegetative growth (length and number of shoots, increment in limb and trunk cross-sectional area, number of nodes, and internode length), production (fruit number, yield, yield efficiency, and fruit size), and return bloom were evaluated from 2010 to 2013. P-Ca efficiently controlled shoot growth in all growing seasons, when applied early in the season, due to the reduction in internode length. Production was not negatively affected by the application of $\mathrm{P}-\mathrm{Ca}$ in all years and at both sites, and fruit size and return bloom were not reduced. Fruit quality attributes were also little affected by $\mathrm{P}-\mathrm{Ca}$, except for total soluble solids content, which was lower than that of the control. This shows that $\mathrm{P}-\mathrm{Ca}$ is efficient to manage tree vigor in high-density 'Starkrimson' pear orchards.
\end{abstract}

Index terms: Pyrus communis, modern orchard, plant growth regulator, vigor control.

\section{Prohexadiona cálcio no crescimento de ramos de pereiras 'Starkrimson'}

Resumo - O objetivo deste trabalho foi avaliar a produção e o crescimento vegetativo de peras 'Starkrimson' em resposta à aplicação de prohexadiona cálcio (P-Ca). Aplicou-se $\mathrm{P}-\mathrm{Ca}\left(250 \mathrm{mg} \mathrm{L}^{-1}\right)$ em ramificações laterais e em plantas inteiras, em pomares comerciais. Utilizou-se o delineamento experimental de blocos ao acaso, para minimizar os efeitos da declividade do terreno. O crescimento vegetativo (comprimento e número de ramos, incremento da área da secção transversal dos ramos laterais e do tronco, número de nós e comprimento de entrenós), a produção (número de frutos, produtividade, eficiência produtiva e tamanho de fruto) e o retorno da floração foram avaliados de 2010 a 2013. P-Ca foi eficiente no controle do crescimento de ramos em todas as safras, quando aplicada no início do ciclo de crescimento, devido à redução no comprimento dos entrenós. A produção não foi afetada negativamente pela aplicação de $\mathrm{P}-\mathrm{Ca}$ em todos os anos e em ambos os locais, e o tamanho de fruto e o retorno da floração não foram reduzidos. Os atributos de qualidade dos frutos também foram pouco afetados por P-Ca, exceto o teor de sólidos solúveis totais, que foi menor que o do controle. Assim, P-Ca é eficiente no manejo do vigor em pomares de alta densidade de peras 'Starkrimson'.

Termos para indexação: Pyrus communis, pomares modernos, reguladores vegetais, controle de vigor.

\section{Introduction}

'Starkrimson', or Red Clapp's Favorite, pear (Pyrus communis $\mathrm{L}$.) is a minor, yet important summer cultivar produced in the United States. This pear variety is known for its inherent vigor, which is not sufficiently controlled by the rootstocks currently available in the country (Elkins et al., 2012), and its trees are also susceptible to fire blight. As a result, most pear orchards are planted at low to moderate tree densities. While these plantings may cost less in the short-term, they limit early returns and future opportunities to improve harvest efficiencies.
In order to overcome this situation, more efficient and profitable systems, such as high-density plantings, are required. For the Conference (Policarpo et al., 2006), Bartlett, Bosc (Robinson, 2011), and Rocha (Pasa et al., 2015) cultivars, for example, pear yield was positively related to planting density. These orchard configurations offer the advantages of early production, sustained high yields of high-quality fruit, and lower labor costs, but their continued success relies on the application of horticultural techniques to control tree size, especially of highly vigorous cultivars. Solutions to balance tree growth and productivity are 
also required for orchards planted at moderate to low densities.

$\mathrm{P}-\mathrm{Ca}$ is a gibberellin (GA) biosynthesis inhibitor used to control the vegetative growth of certain tree-fruit crops, by reducing the levels of bioactive $\mathrm{GA}_{1}$ and $\mathrm{GA}_{4}$, resulting in the accumulation of its precursor, $\mathrm{GA}_{20}$ (inactive), in plant tissues (Kang et al., 2010). Previous studies have shown marked vigor management of several pear cultivars by P-Ca (Smit et al., 2005; Asín et al., 2007; Einhorn et al., 2014; Pasa \& Einhorn, 2014; Carra et al., 2016). However, deleterious effects on return bloom (Smit et al., 2005; Einhorn et al., 2014) and fruit size (Elfving et al., 2003) have been observed. Despite this, localized applications of P-Ca effectively reduced the growth of individual shoots, as observed in a high-density 'd'Anjou' pear orchard, without any apparent translocation to adjacent, untreated shoots (Pasa \& Einhorn, 2014). Furthermore, the application of $\mathrm{P}-\mathrm{Ca}$ to tops of mature pear trees reduced growth and improved intracanopy light relationships (Elfving et al., 2003), besides markedly reducing labor costs associated with pruning (Elfving et al., 2003). This shows the importance of incorporating $\mathrm{P}-\mathrm{Ca}$ into precision management programs targeting canopy tops or other high-vigor areas, without predisposing the rest of the canopy of sensitive cultivars to the deleterious effects of P-Ca.

It should be noted that, depending on the cultivar and environmental conditions, plant response to P-Ca may vary (Smit et al., 2005), illustrating a major limitation when transposing P-Ca results from one cultivar to another or from one region to another (Einhorn et al., 2014). In addition, vigor is positively related to canopy height and, with time, can reduce the light environment of the lower tiers of the canopy (Musacchi, 2011); light levels have also been positively correlated with fruit set, ensuing pear yield (Einhorn et al., 2012).

The objective of this work was to evaluate the fruiting and vegetative growth of 'Starkrimson' pear in response to the application of prohexadione calcium (P-Ca).

\section{Materials and Methods}

The experimental plots were established in 2010 and 2011, respectively, at the Mid-Columbia Agricultural Research \& Extension Center of Oregon State University, in the lower Hood River Valley $\left(45^{\circ} 41^{\prime} 07^{\prime \prime} \mathrm{N}\right.$, $121^{\circ} 31^{\prime} 00^{\prime \prime} \mathrm{W}$ ), and in commercial orchards in Parkdale $\left(45^{\circ} 31^{\prime} 12^{\prime \prime} \mathrm{N}, 121^{\circ} 36^{\prime} 42^{\prime \prime} \mathrm{W}\right)$, in the upper Hood River Valley, both in the state of Oregon, in the United States. Weather conditions during the experiments, from 2010 to 2013, are presented in Figure 1 (AgriMet, 2015). At all sites, trees were selected for uniformity (canopy volume) and blocked according to land slope. Solutions (mg L-1 a.i.) of prohexadione calcium, Apogee, (BASF Corporation, Research Triangle Park, NC, USA) were supplemented with $0.1 \%$ (v:v) nonionic surfactant, Simulaid, (Genesis Agri-products Inc., Union Gap, WA, USA) and were applied for uniform and complete coverage of either entire scaffold limbs, in 2010 and 2011, or whole trees, in 2012. A hydraulic pressurized spray gun (300 psi), NIFTY Series Utility Sprayer, (Rears Manufacturing Company, Coburg, OR, USA) was used to apply treatments to whole canopies. A $\mathrm{CO}_{2}$ backpack sprayer, with less boom, model D, (Bellspray, Inc., Opelousas, LA, USA), was used for scaffold applications in 2010 and 2011.

In 2010, 11-year-old 'Starkrimson' pears grafted on $\mathrm{OH} \times \mathrm{F} 97$ rootstocks were selected from an orchard trained to a central-leader system $(2.8 \times 4.6 \mathrm{~m}$, with 797 trees per hectare). In 2011, 19-year-old 'Starkrimson' pears grafted on $\mathrm{OH} \times \mathrm{F} 97$ rootstocks were chosen from an adjacent orchard trained to a central-leader system (3.7x4.9 m, with 560 trees per hectare). In both years, trees were arranged in randomized complete block designs and one primary scaffold was selected per tree to receive the treatments. Two treatments, each with six replicates, were evaluated: control, unsprayed; and P-Ca (250 $\left.\mathrm{mg} \mathrm{L}^{-1}\right)$ applied once. The application was performed when shoots were $\sim 10 \mathrm{~cm}$ long, on 5/10/2010 and 5/7/2011, $\sim 25$ days after full bloom; scaffolds were sprayed to the point of runoff, which was equivalent to approximately $1 \mathrm{~L}$ per tree. No second $\mathrm{P}-\mathrm{Ca}$ application was made, since regrowth was not observed in either year. The soil of the experimental area is classified as a Parkdale loam (USDA, 1997).

Another experiment was carried out in 2012, in a 7-year-old 'Starkrimson' orchard (3.6x1.2 m, with $\sim 2,300$ trees per hectare, $\sim 3.7 \mathrm{~m}$ canopy height, and north:south row orientation) on $\mathrm{OH} \times \mathrm{F} 87$ rootstocks, trained to a planar, vertical, 8-wire hedgerow system. The soil of the area is classified as a fine sandy loam from the Van Horn series (USDA, 2002). Single-tree replicates were distributed in a randomized complete block design with five replicates per treatment, which 

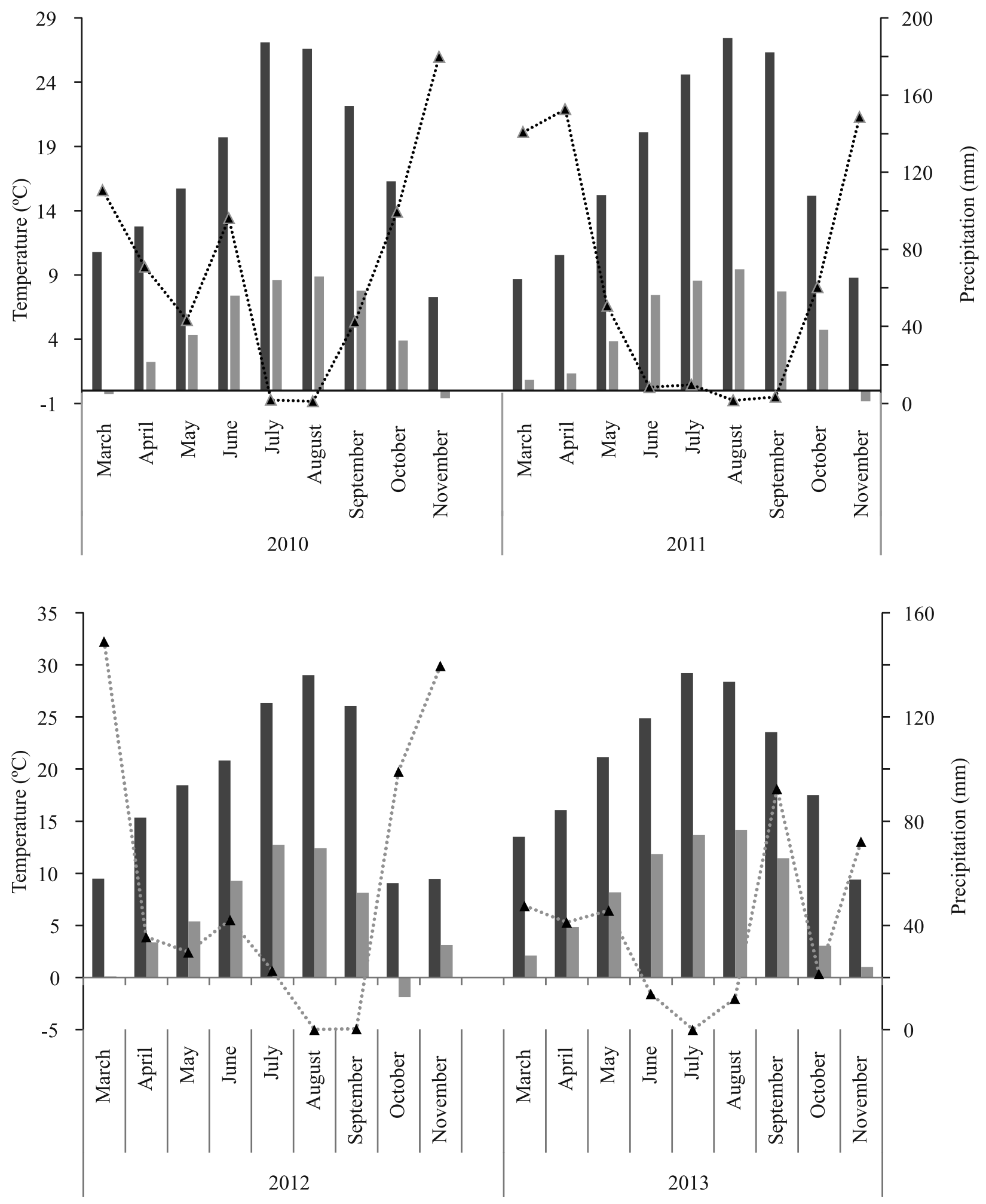

Monthly average of maximum temperatures $\quad$ Monthly average of minimum temperatures
$\cdots$ Monthly precipitation

Figure 1. Weather conditions of the experimental field located in Parkdale, Oregon, in 2010 and 2011, and in Hood River, Oregon, in 2012 and 2013. Source: AgriMet (2015). 
were: control, unsprayed; P-Ca (250 $\left.\mathrm{mg} \mathrm{L}^{-1}\right)$ applied once; and $\mathrm{P}-\mathrm{Ca}\left(250 \mathrm{mg} \mathrm{L}^{-1}\right)$ applied twice. Application was performed when shoots were $\sim 5 \mathrm{~cm}$ long, on 4/29/2012, approximately seven days after full bloom; trees were sprayed to the point of runoff, which was equivalent to approximately $1 \mathrm{~L}$ per tree. The second $\mathrm{P}-\mathrm{Ca}$ application in the third treatment was intended to coincide with growth resumption, which did not occur, so spraying was also done only once.

Current-season shoots were selected based on the uniformity and position of the 1-year-old trunk they were emerging from and were tagged prior to the application of P-Ca. The number of shoots varied with each experiment, primarily due to the experimental unit, i.e., scaffold limb vs. whole canopy, and was of: eight, six, and ten shoots per replicate in 2010, 2011, and 2012, respectively, measured at a weekly interval until the end of the season.

In 2010 and 2011, the total number and length of current-season shoots per scaffold limb, in addition to the measurement shoots previously described, were determined. In 2011, the number of nodes per shoot was also counted, whereas, in 2012, the number of nodes on all measurement shoots was counted at the end of the growing season. Based on shoot length and node incidence, average internode length $(\mathrm{cm})$ and node density (number of nodes per centimeter of shoot length) were derived. Moreover, six primary scaffold limbs per replicate tree were also selected before the treatments were applied, in order to characterize the annual growth response of the tree. In the fall, the total number of new shoots and the cumulative currentseason extension growth were determined on the scaffold limbs.

Scaffold limbs, in 2010-2011, and trunk circumference, in 2012, were measured $10 \mathrm{~cm}$ from their point of origin and at $20 \mathrm{~cm}$ above the graft union, respectively, at the beginning of the trial and when leaves were abscised in the fall. Full bloom was observed on 5/3/2010, 5/21/2011, 4/23/2012, and $4 / 10 / 2013$. Multiple freeze events occurred prior to anthesis in 2010, resulting in high flower mortality. Return bloom was expressed as the percentage of spurs or shoots with flower clusters and was measured the year after treatment application on all spurs and on 1-year-old shoots per scaffold limb, in 2010-2011, or on the entire canopy, in 2012.
Scaffold limbs, in 2010-2011, or whole trees, in 2012, were harvested at commercial timing, on $7 / 6 / 2010,7 / 14 / 2011$, and 8/14/2012. Return yield from the treatments in 2012 was assessed on $8 / 7 / 2013$, when all fruits were weighed and counted. The average weight per fruit was calculated based on the total population of fruits harvested in 2010 and 2011, and on a random sample of 100 fruit per tree in 2012 and 2013.

At harvest, fruit firmness (FF) was measured on 20 randomly selected fruit using a fruit texture analyzer, with an $8-\mathrm{mm}$ diameter probe [Güss Manufacturing (Pty) Ltd., Strand, South Africa]. Sections of skin, $\approx 2$ $\mathrm{cm}$ in diameter, were removed at the widest point of the fruit on opposite sides prior to the determination of FF. An additional 30 fruit per replicate tree were immediately placed in regular air cold storage (RACS), at $-1^{\circ} \mathrm{C}$, after harvest and analyzed at two months to determine fruit quality. Fifteen fruit were analyzed right after removal from cold storage, and the remaining 15 fruit after a ripening period (RT) of seven days, at $20^{\circ} \mathrm{C}$. Firmness was assessed as described before. After FF measurements, a composite sample of fruit tissue per replicate was juiced in a heavy-duty juice extractor, model 6001C, (Waring Products, New Hartford, CT, USA), and $0.5 \mathrm{~mL}$ of juice was pipetted onto a Palette series digital refractometer, PR-101a, (Atago U.S.A, Inc., Bellevue, WA, USA) to determine soluble solids (SS) content (Einhorn et al., 2012). Titratable acidity (TA), equivalent to malic acid, was determined using $10 \mathrm{~mL}$ of juice $+10 \mathrm{~mL}$ of deionized water, which was titrated with $0.1 \mathrm{~N}$ sodium hydroxide to an end point $\mathrm{pH}$ of 8.1 using a titrator fitted with an automated sampler, DL15 and Rondolino, (MettlerToledo Inc., Zurich, Switzerland), according to Einhorn et al. (2012). Juice from $100 \mathrm{~g}( \pm 0.5 \mathrm{~g})$ of fresh fruit $(\approx 10$ g slice taken from each sample) was transferred to a graduated cylinder for determination of extractable juice (Einhorn et al., 2012), which has been shown to be a good ripening indicator.

Statistical analyses were performed using the $\mathrm{R}$ software (R Foundation for Statistical Computing, 2014), and data were analyzed for statistical significance by the F-test.

\section{Results and Discussion}

P-Ca significantly reduced shoot growth when compared with that of the control, in approximately 
55,67 , and $46 \%$ by the fall of 2010,2011 , and 2012 , respectively (Figure 2). Differences were apparent at approximately four to five weeks after the treatment, depending on the year.
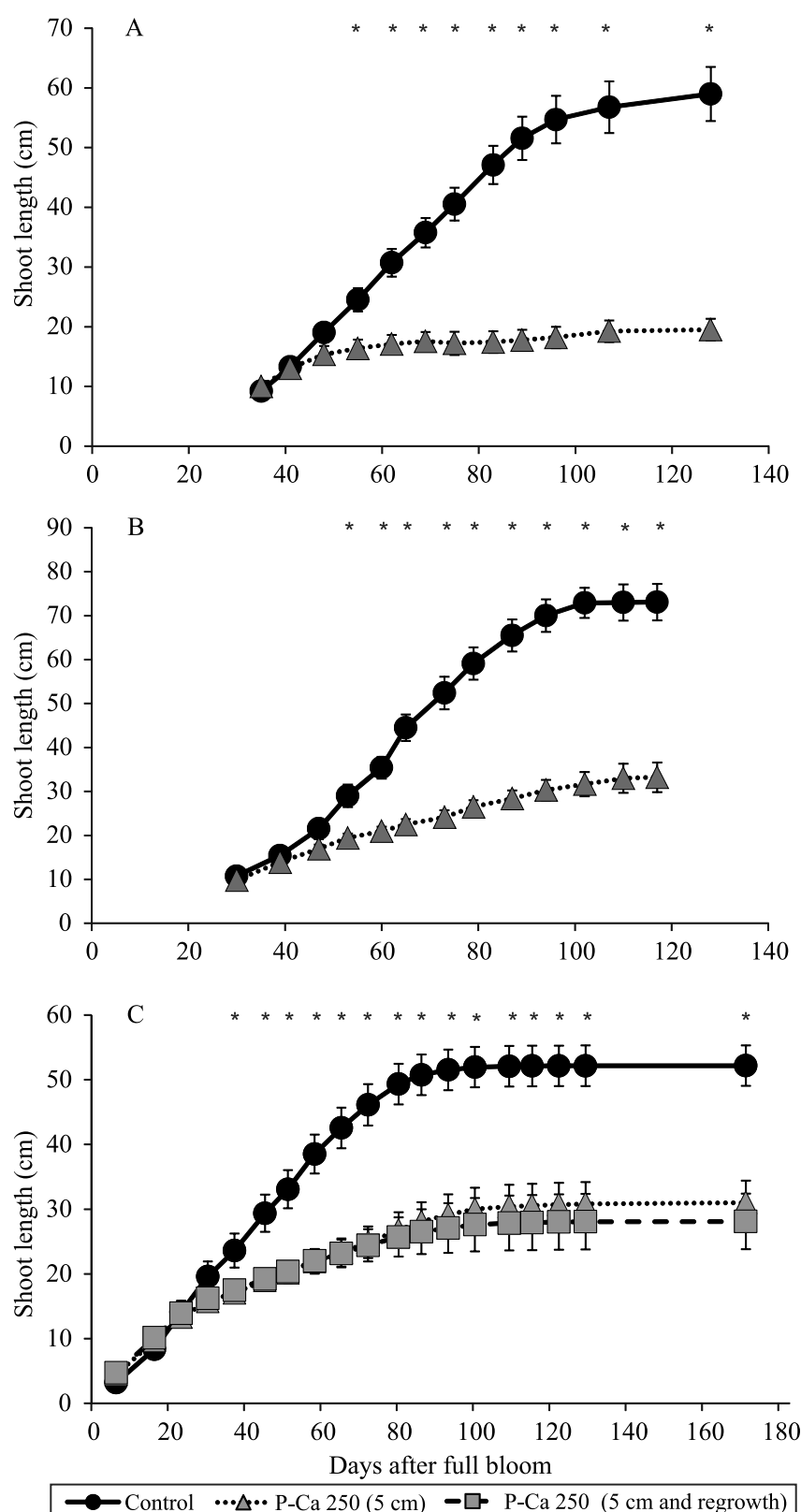

Figure 2. Effects of the application of prohexadione calcium (P-Ca) on shoot length of 'Starkrimson' pear (Pyrus communis) in 2010 (A), 2011 (B), and 2012 (C). Asterisks at the top of the graphs indicate that differences between means are statistically significant, according to the F-test, at $5 \%$ probability. Vertical bars represent standard error. Means of five replicate plots $(n=10)$.
The response of 'Starkrimson' shoots to P-Ca was consistent with that found in previous studies (Elfving et al., 2003; Costa et al., 2004; Smit et al., 2005; Asín et al, 2007; Hawerroth et al., 2012; Einhorn et al., 2014; Pasa \& Einhorn, 2014; Carra et al., 2016), in which shoot growth was significantly reduced in comparison with the untreated control treatments. The difference is that, in the present study, only a single P-Ca application was necessary to control shoot growth during the season in all years (Figure 2). These data contrast with those of Einhorn et al. (2014), who reported a characteristic second flush of growth for highly vigorous pear cultivars, which was not observed in the present study, irrespectively of treatment or year. A probable reason for this is that 'Starkrimson' is more vigorous than 'd'Anjou', which was evaluated by Einhorn et al. (2014), indicating that the rate tested was not strong enough to completely check shoot growth. Indeed, the optimum rate should not stop shoot growth, but rather slow it down, in order to avoid secondary growth flushes. Shoot initiation of 'Starkrimson' was reduced by P-Ca in 2010, but not in 2011 and 2012, showing inconsistency among years, as previously reported (Asín et al., 2007). Therefore, the combination fewer shoots and less shoot extension was ultimately responsible for the overall effect.

The cumulative current-season length of shoots originating from scaffold limbs was significantly reduced by $\mathrm{P}-\mathrm{Ca}$, which was predominantly associated with shorter shoots in all years and also to fewer shots in 2010 (Table 1). P-Ca also affected shoot morphology when evaluated, by significantly reducing internode length and increasing node density. The number of nodes per shoot was significantly reduced in 2011 but not in 2012. In addition, an inconsistent effect of $\mathrm{P}-\mathrm{Ca}$ on incremental scaffold or trunk growth was also observed. The markedly higher increase in the percentage of limb cross-sectional area in 2010, in comparison with 2011, regardless of the treatment, was attributed to the difference in the starting size of the scaffolds, i.e., 11-year-old trees in 2010 vs. 19-year-old trees in 2011.

Besides exhibiting less extension growth, shoots treated with $\mathrm{P}-\mathrm{Ca}$ had shorter internodes and greater node density than the untreated ones, mostly due to the inhibitory $\mathrm{P}-\mathrm{Ca}$ effect over growth-active $\mathrm{GA}_{1}$ (Kang et al., 2010), which is responsible for 
internode elongation. Similar results were reported for 'd'Anjou' pear (Einhorn et al., 2014; Pasa \& Einhorn, 2014) and 'Starkrimson' apple (Çetinbaş et al., 2015). This change in the development of shoots should lead to more compact trees with higher fruiting efficiency.
At harvest, fruit number, fruit density, yield, yield efficiency, and average fruit size were not affected by $\mathrm{P}-\mathrm{Ca}$ in any year (Tables 2 and 3). The return bloom of spurs and 1-year-old shoots was unaffected by P-Ca in two of the three evaluated years and was significantly greater following P-Ca treatment in 2011 (Table 2).

Table 1. Effect of prohexadione calcium application on the vegetative processes of 'Starkrimson' pear (Pyrus communis) trees and scaffold limbs ${ }^{(1)}$.

\begin{tabular}{|c|c|c|c|}
\hline Treatment & Control & $\begin{array}{l}\text { Prohexadione calcium (250 } \\
\left.\mathrm{mg} \mathrm{L}^{-1}\right)\end{array}$ & $\mathrm{P}>\mathrm{F}$ \\
\hline & & 2010 & \\
\hline Total shoot length ( $\left.\mathrm{cm} \mathrm{cm}^{-2} \mathrm{LCSA}\right)$ & 225.90 & 117.90 & 0.001 \\
\hline Shoots (number per square centimeter LCSA) & 4.31 & 2.98 & 0.039 \\
\hline Average shoot length $(\mathrm{cm})$ & 55.10 & 38.90 & 0.007 \\
\hline \multirow[t]{2}{*}{ LCSA increment (\%) } & 35.01 & 25.90 & 0.069 \\
\hline & & 2011 & \\
\hline Total shoot length $\left(\mathrm{cm} \mathrm{cm}^{-2}\right.$ LCSA) & 76.10 & 20.80 & 0.010 \\
\hline Shoots (number per square centimeter LCSA) & 2.28 & 1.33 & 0.223 \\
\hline Average shoot length $(\mathrm{cm})$ & 36.20 & 14.80 & $<0.001$ \\
\hline LCSA increment (\%) & 4.60 & 1.60 & 0.050 \\
\hline Number of nodes & 13.20 & 7.40 & $<0.001$ \\
\hline Average internode length $(\mathrm{cm})$ & 2.73 & 1.96 & $<0.001$ \\
\hline \multirow[t]{2}{*}{ Node density (nodes per centimeter) } & 0.37 & 0.51 & $<0.001$ \\
\hline & & 2012 & \\
\hline Total shoot length ( $\left.\mathrm{cm} \mathrm{cm}^{-2} \mathrm{LCSA}\right)$ & 70.84 & 38.62 & 0.043 \\
\hline Shoots (number per square centimeter LCSA) & 3.33 & 3.73 & 0.290 \\
\hline Average shoot length $(\mathrm{cm})$ & 22.47 & 10.89 & 0.015 \\
\hline Trunk cross-sectional area increment (\%) & 26.45 & 28.20 & 0.286 \\
\hline Number of nodes & 22.24 & 20.20 & 0.273 \\
\hline Average internode length $(\mathrm{cm})$ & 2.25 & 1.35 & $<0.001$ \\
\hline Node density (nodes per centimeter) & 0.46 & 0.83 & 0.003 \\
\hline
\end{tabular}

${ }^{(1)}$ Means were separated by the F-test, at 5\% probability. Data are means of six individual scaffold replicates, in 2010 and 2011, and of five individual tree replicates, in 2012. LCSA, limb cross-sectional area.

Table 2. Effect of the application of prohexadione calcium in 2010 and 2011 on the reproductive processes of 'Starkrimson' pear (Pyrus communis) trees ${ }^{(1)}$.

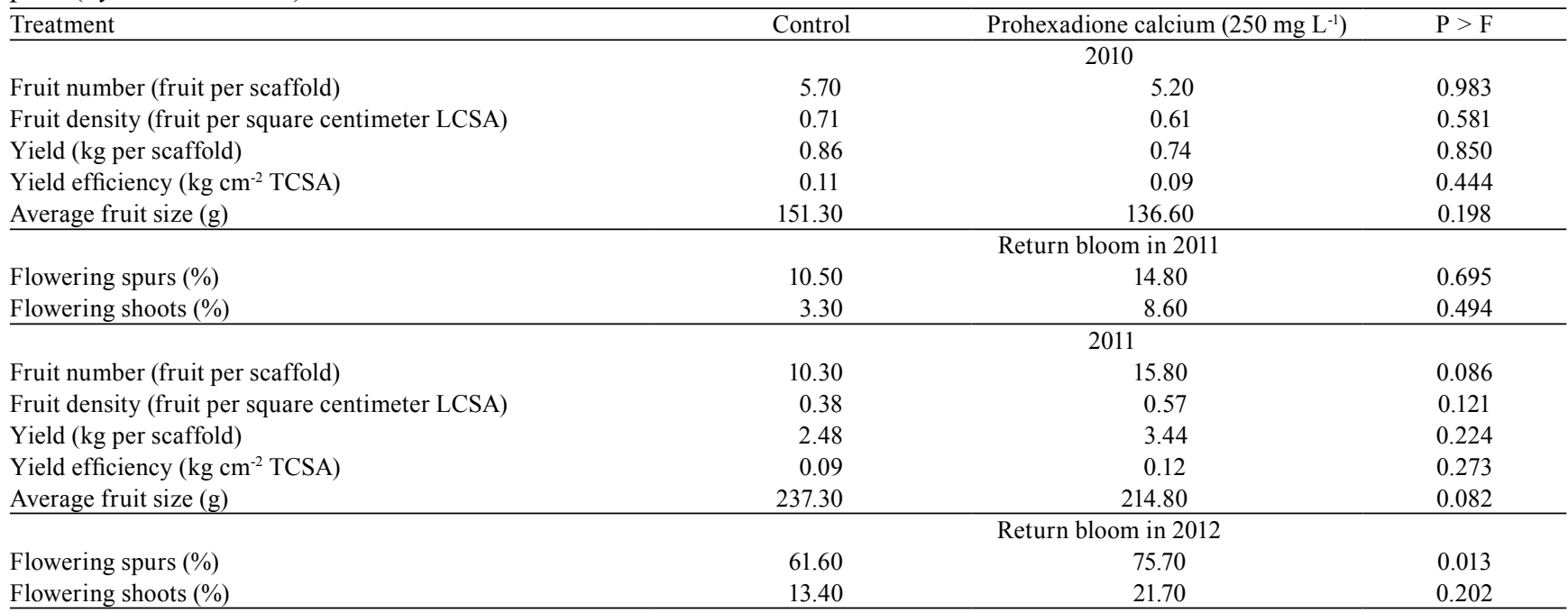

${ }^{(1)}$ Means were separated by the F-test, at $5 \%$ probability. Data are means of five replicates. LCSA, limb cross-sectional area; and TCSA, trunk cross-sectional area. 
Whole canopy return yield, fruit number, and average fruit size were not significantly affected by $\mathrm{P}-\mathrm{Ca}$ treatment in 2012 (Table 3).

Fruit production parameters were also not affected by P-Ca application (Tables 2 and 3). However, a positive effect of $\mathrm{P}-\mathrm{Ca}$ on pear fruit set has been reported (Costa et al., 2004; Smit et al., 2005), although not consistently (Sugar et al., 2004; Asín et al., 2007; Einhorn et al., 2014). Yield increase in response to $\mathrm{P}-\mathrm{Ca}$ was observed in one out of three years of a study with 'd'Anjou' pear (Einhorn et al., 2014), but tends to vary according to cultivars and years (Smit et al., 2005; Asín et al., 2007; Hawerroth et al., 2011; Carra et al., 2016), indicating that several factors contribute to the effect. Although it might be expected that the isolated treatment of scaffold limbs would differ from that of whole canopies, this was not observed either in the present study or in the one with 'd'Anjou' pear (Einhorn et al., 2014). Due to the difficulty of evaluating fruit set in whole trees, some studies have estimated it based on scaffolds, but the results may differ from those obtained using whole trees. Considering the first seasons, when P-Ca was tested on scaffold limbs in the last experimental year, the results for estimated fruit set based on whole trees, i.e., counting of the total number of flowers and fruits of each tree, were similar to those found using scaffold limbs. Cultivar, rootstock/scion combinations, crop load, and hormonal balance are expected to interact with the application dose and timing of $\mathrm{P}-\mathrm{Ca}$ associated with the environmental conditions before, during, and after applications
(Stover \& Greene, 2005). This would explain the different effects of P-Ca on pear fruit set among studies.

P-Ca (trade name Apogee), for example, reduced fruit size of 'Bartlett' in the year of application and return bloom of 'Bosc' (Elfving et al., 2003), which is why it is no longer labelled for use with pear in the United States. However, 'd'Anjou' fruit size was either not reduced by P-Ca (Elfving et al., 2003; Sugar et al., 2004) or was reduced in one of three study years, which was partially explained by the higher crop load (Einhorn et al., 2014). A negative association of P-Ca with return bloom was observed only in the latter experiment, though this was more likely attributed to an effect of crop load in the previous year. Independently of the treatment, lower return bloom on P-Ca-treated trees did not equal to a commensurate reduction in return yield (Einhorn et al., 2014). However, P-Ca had no adverse effect on return bloom and production of 'Starkrimson'. Collectively, these data support the use of P-Ca on 'Starkrimson' trees to manage vigor.

FF was not affected by P-Ca at harvest, following cold storage, or after ripening (Table 4). However, SS were reduced by P-Ca at harvest, an effect which was maintained after two months of RACS and RT. P-Ca generally led to lower TA and higher extractable juice, though not consistently at significant levels. Fruit quality at harvest and following cold storage was only slightly affected by $\mathrm{P}-\mathrm{Ca}$, as similarly reported for 'd'Anjou' pear (Einhorn et al., 2014). The combination of lower SS and TA following P-Ca indicates that P-Catreated fruit may have been developmentally delayed.

Table 3. Effect of the application of prohexadione calcium in 2012 on the reproductive processes of 'Starkrimson' pear (Pyrus communis) trees ${ }^{(1)}$.

\begin{tabular}{|c|c|c|c|}
\hline Treatments & Control & Prohexadione calcium $\left(250 \mathrm{mg} \mathrm{L}^{-1}\right)$ & $\mathrm{P}>\mathrm{F}$ \\
\hline & \multicolumn{3}{|c|}{2012} \\
\hline Fruit number (fruit per tree) & 125.00 & 146.60 & 0.383 \\
\hline Fruit density (fruit per square centimeter TCSA) & 3.25 & 2.96 & 0.714 \\
\hline Yield (kg per tree) & 24.57 & 29.87 & 0.181 \\
\hline Yield efficiency ( $\mathrm{kg}$ per square centimeter TCSA) & 0.63 & 0.60 & 0.811 \\
\hline \multirow[t]{2}{*}{ Average fruit size $(\mathrm{g})$} & 199.43 & 205.78 & 0.700 \\
\hline & \multicolumn{3}{|c|}{ Return bloom and yield in 2013} \\
\hline Flowering spurs (\%) & 37.30 & 22.43 & 0.110 \\
\hline Flowering shoots $(\%)$ & 15.90 & 36.42 & 0.134 \\
\hline Yield (kg per tree) & 26.60 & 21.73 & 0.308 \\
\hline Fruit number (fruit per tree) & 114.40 & 87.71 & 0.232 \\
\hline Average fruit size $(\mathrm{g})$ & 234.80 & 254.10 & 0.224 \\
\hline
\end{tabular}

${ }^{(1)}$ Means were separated by the F-test, at 5\% probability. Data are means of five replicates. TCSA, trunk cross-sectional area. 
Table 4. Effect of the application of prohexadione calcium on 'Starkrimson' pear (Pyrus communis) fruit quality at harvest, immediately following two months of regular air cold storage (RACS), at $-1^{\circ} \mathrm{C}$, and after a ripening period (RT) of seven days, at $20^{\circ} \mathrm{C}^{(1)}$.

\begin{tabular}{|c|c|c|c|}
\hline Treatment & Control & Prohexadione calcium $\left(250 \mathrm{mg} \mathrm{L}^{-1}\right)$ & $\mathrm{P}>\mathrm{F}$ \\
\hline \multicolumn{4}{|c|}{ At harvest } \\
\hline Firmness $(\mathrm{N})$ & 13.97 & 13.54 & 0.293 \\
\hline Soluble solids $\left({ }^{\circ}\right.$ brix $)$ & 12.32 & 11.02 & 0.034 \\
\hline Extractable juice $\left(\mathrm{mL} 100 \mathrm{~g}^{-1} \mathrm{FW}\right)$ & 68.00 & 69.40 & 0.431 \\
\hline Titratable acidity $(\%)$ & 0.43 & 0.37 & 0.261 \\
\hline \multicolumn{4}{|c|}{ Two months of RACS } \\
\hline Firmness $(\mathrm{N})$ & 13.75 & 13.30 & 0.298 \\
\hline Soluble solids $\left({ }^{\circ}\right.$ brix $)$ & 12.88 & 11.88 & 0.054 \\
\hline Extractable juice $\left(\mathrm{mL} 100^{-1} \mathrm{FW}\right)$ & 69.90 & 71.86 & 0.087 \\
\hline Titratable acidity $(\%)$ & 0.34 & 0.30 & 0.053 \\
\hline \multicolumn{4}{|c|}{ Two months of RACS + seven days after RT } \\
\hline Firmness $(\mathrm{N})$ & 1.43 & 1.37 & 0.555 \\
\hline Soluble solids $\left({ }^{\circ}\right.$ brix $)$ & 13.08 & 11.86 & 0.039 \\
\hline Extractable juice (mL $\left.100 \mathrm{~g}^{-1} \mathrm{FW}\right)$ & 43.48 & 51.10 & 0.055 \\
\hline Titratable acidity $(\%)$ & 0.37 & 0.34 & 0.031 \\
\hline
\end{tabular}

${ }^{(1)}$ Means were separated by the F-test, at 5\% probability. Data are means of five replicates. FW, fresh weight.

However, they were capable of achieving ripening capacity following two months of RACS, as shown by flesh softening.

\section{Conclusions}

1. Prohexadione calcium (P-Ca) effectively controls shoot growth of 'Starkrimson' pear (Pyrus communis).

2. Fruit size, yield, and return bloom are not negatively affected by P-Ca.

3. Fruit quality attributes, at harvest and after cold storage, are little affected by P-Ca.

\section{References}

AGRIMET: historical archive weather data access. Available at: $<$ http://www.usbr.gov/pn/agrimet/wyreport.html $>$. Accessed on: Dec. 202015.

ASÍN, L.; ALEGRE, S.; MONTSERRAT, R. Effect of paclobutrazol, prohexadione-Ca, deficit irrigation, summer pruning and root pruning on shoot growth, yield, and return bloom in a 'Blanquilla' pear orchard. Scientia Horticulturae, v.113, p.142-148, 2007. DOI: 10.1016/j.scienta.2007.02.008.

CARRA, B.; PASA, M.S.; FACHINELLO, J.C.; SPAGNOL, D.; ABREU, E.S.; GIOVANAZ, M.A. Prohexadione calcium affects shoot growth, but not yield components, of 'Le Conte' pear in warm-winter climate conditions. Scientia Horticulturae, v.209, p.241-248, 2016. DOI: 10.1016/j.scienta.2016.06.036.

ÇETINBAŞ, M.; BUTAR, S.; ATASAY, A.; İŞÇI, M.; KOÇAL, $\mathrm{H}$. Reduction of apple vegetative shoot growth cv. Starcrimson Delicious/MM 111 with prohexadione calcium application does not decrease fruit quality. Journal of Applied Botany and Food Quality, v.88, p.259-263, 2015. DOI: 10.5073/ JABFQ.2015.088.038.

COSTA, G.; SABATINI, E.; SPINELLI, F.; ANDREOTTI, C.; SPADA, G.; MAZZINI, F. Prohexadione-Ca controls vegetative growth and cropping performance in pear. Acta Horticulturae, v.653, p.127-132, 2004. DOI: 10.17660/ActaHortic.2004.653.16.

EINHORN, T.C.; PASA, M.S.; TURNER, J. 'd'Anjou' pear shoot growth and return bloom, but not fruit size, are reduced by prohexadione-calcium. HortScience, v.49, p.180-187, 2014.

EINHORN, T.C.; TURNER, J.; LARAWAY, D. Effect of reflective fabric on yield of mature 'd'Anjou' pear trees. HortScience, v.47, p.1580-1585, 2012.

ELFVING, D.C.; LOMBARDINI, L.; MCFERSON, J.R.; DRAKE, S.R.; FAUBION, D.F.; AUVIL, T.D.; VAN EE, G.; VISSER, D.B. Effects of directed applications of prohexadionecalcium to tops of mature pear trees on shoot growth, light penetration, pruning and fruit quality. Journal of the American Pomological Society, v.57, p.45-57, 2003.

ELKINS, R.; BELL, R.; EINHORN, T. Needs assessment for future US pear rootstock research directions based on the current state of pear production and rootstock research. Journal of the American Pomological Society, v.66, p.153-163, 2012.

HAWERROTH, F.J.; HERTER, F.G.; FACHINELLO, J.C.; PETRI, J.L.; PREZOTTO, M.E.; HAAS, L.B.; PRETTO, A. Aumento da produção de pereira asiática pelo uso de fitorreguladores. Ciência Rural, v.41, p.1750-1754, 2011. DOI: 10.1590/S010384782011001000012 .

HAWERROTH, F.J.; PETRI, J.L.; FACHINELLO, J.C.; HERTER, F.G.; PREZOTTO, M.E.; HASS, L.B.; PRETTO, A. Redução da poda hibernal e aumento da produção de pereiras 'Hosui' pelo uso 
de prohexadiona cálcio. Pesquisa Agropecuária Brasileira, v.47, p.939-947, 2012. DOI: 10.1590/S0100-204X2012000700010.

KANG, S.-M.; KIM, J.-T.; HAMAYUN, M.; HWANG, I.-C.; KHAN, A.L.; KIM, Y.-H.; LEE, J.-H.; LEE, I.-J. Influence of prohexadione-calcium on growth and gibberellins content of Chinese cabbage grown in alpine region of South Korea. Scientia Horticulturae, v.125, p.88-92, 2010. DOI: 10.1016/j. scienta.2010.02.018.

MUSACCHI, S. Training system and management for a high density orchard of 'Abbé Fetel'. Acta Horticulturae, v.909, p.225240, 2011. DOI: 10.17660/ActaHortic.2011.909.25.

PASA, M. da S.; FACHINELLO, J.C.; ROSA JÚNIOR, H.F. da; FRANCESCHI, É. de; SCHMITZ, J.D.; SOUZA, A.L.K. de. Performance of 'Rocha' and 'Santa Maria' pears as affected by planting density. Pesquisa Agropecuária Brasileira, v.50, p.126131, 2015. DOI: 10.1590/S0100-204X2015000200004.

PASA, M.S.; EINHORN, T.C. Heading cuts and prohexadionecalcium affect the growth and development of 'd'Anjou' pear shoots in a high-density orchard. Scientia Horticulturae, v.168, p.267-271, 2014. DOI: 10.1016/j.scienta.2014.02.003.

POLICARPO, M.; TALLUTO, G.; LO BIANCO, R. Vegetative and productive responses of 'Conference' and 'Williams' pear trees planted at different in-row spacings. Scientia Horticulturae, v.109, p.322-331, 2006. DOI: 10.1016/j.scienta.2006.06.009.
R FOUNDATION FOR STATISTICAL COMPUTING. R: a language and environment for statistical computing. Vienna, 2014.

ROBINSON, T.L. High density pear production with Pyrus communis rootstocks. Acta Horticulturae, v.909, p.259-270, 2011. DOI: 10.17660/ActaHortic.2011.909.28.

SMIT, M.; MEINTJES, J.J.; JACOBS, G.; STASSEN, P.J.C.; THERON, K.I. Shoot growth control of pear trees (Pyrus communis L.) with prohexadione-calcium. Scientia Horticulturae, v.106, p.515-529, 2005. DOI: 10.1016/j.scienta.2005.05.003.

STOVER, E.W.; GREENE, D.W. Environmental effects on the performance of foliar applied plant growth regulators: a review focusing on tree fruits. HortTechnology, v.15, p.214-221, 2005.

SUGAR, D.; ELFVING, D.C.; MIELKE, E.A. Effects of prohexadione-calcium on fruit size and return bloom in pear. HortScience, v.39, p.1305-1308, 2004.

USDA. United States Department of Agriculture. Parkdale series. 1997. Web site for official soil series descriptions and series classification. Available at: <https://soilseries.sc.egov.usda.gov/ OSD_Docs/P/PARKDALE.html>. Accessed on: July 262016.

USDA. United States Department of Agriculture. Van Horn series. 2002. Web site for official soil series descriptions and series classification. Available at: <https://soilseries.sc.egov.usda.gov/ OSD_Docs/V/VAN_HORN.html>. Accessed on: July 262016.

Received on December 22, 2015 and accepted on July 28, 2016 